\title{
An inventory of soils and soil suitabilities in West Irian. I
}

\section{H. SCHROO}

Chief soil scientist, from 1956 to 1962 , in the former Government of Netherlands New Guinea

\section{Contents}

\section{PART I : GENERAL INFORMATION}

\section{Introduction}

1.1. Historical notes

1.2. Objectives and principles of soil research

1.3. Evaluation of available soil maps

1.4. Possible design of a regional soil map

2. Environmental conditions of soil genesis
2.1. Climate
2.2. Vegetation
2.3. Topography and hydrology
2.4. Parent materials
2.5. General pattern of genetic soil types

3. Soilsuitability, soil quality and methods of analysis

3.1. Soil suitability

3.2. Soil quality

3.3. Sampling technique used in soil-fertility appraisal

3.4. Methods of analysis

\section{PART II : SPECIFIED INFORMATION}

4. Soil suitabilities in localities specially investigated

A. 4.1. Explanatory remarks

4.2. North coast, section east of Sermo river

4.3. North coast, section east of Sarmi

4.4. The islands of Japan, Biak and Noemfoer

4.5. The Waropen coast

4.6. East coast of Vogelkop Peninsula

4.7. Northern part of Vogelkop Peninsula

B. 4.8. Southern part of Vogelkop Peninsula

4.9. West coast, section MacCluer Gulf-Etna Bay

4.10. Central Mountains

4.11. Southwest coast

4.12. Digoel drainage basin

4.13. Southern coastal plains

$\begin{array}{lr}\text { Objects } & 1-4 \\ \text { Object } & 5 \\ \text { Objects } & 6-8 \\ \text { Objects } & 9-11 \\ \text { Objects } & 12-15 \\ \text { Objects } & 16-20 \\ \text { Object } & 21 \\ \text { Objects } & 22-23 \\ \text { Objects } & 24 a-24 b \\ \text { Object } & 25 \\ \text { Objects } & 26-29 \\ \text { Objects } & 30-31\end{array}$

Acknowledgements

Note :

Owing to the unusually large extent of the present article it has been decided to publish it in three parts, viz. Part I in this issue No. 4 (Aug., 1963); Part II A in No. 5 (Nov. 1963); Part II B in No. 1 (Feb., 1964).

Received for publication 1st July, 1963. 


\section{Summary}

In aid of future agricultural developments of West Irian, a review is presented of the practical knowledge that has been compiled about West Irian soils by Dutch soil scientists which have been working in the former Netherlands New Guinea.

In the first three chapters (PART I), general information is brought together concerning principles and methods of investigation and also about the dominant environmental conditions of soil formation and land-use potentials.

The point is stressed that the investigations of West Irian soils has been aimed primarily at a rapid inventory and appraisal of, mainly, alluvial soils in accessible parts of the country. The aspects of soil systematics and nomenclature have thus received less attention.

Under the prevailing conditions of high and continuous rainfall, and because of the very immature geomorphology of the mountainous country, soil formation in West Iirian is dynamic and subject to continuous rejuvenation.

Nevertheless, soil fertility is generally low because the mineral composition of parent rock or materials is predominantly poor, and combines unfauvourably with excessive leaching of soils in this humid tropical country.

In the fourth chapter (PART II) of this review more detailed information is presented about soils and soil suitabilities which are met with in each of the 31 objects where soil surveys have been conducted. A standard set of analytical data will enable the comparison of the fertility of the various soils under discussion.

This review is not meant to replace, but only to facilitate entry to, the classified data contained in the original soil reports, listed in Annex II.

\section{Part I: General information}

\section{Introduction}

\subsection{Historical notes}

The termination of Dutch government in West New Guinea on 1st October, 1962, marked the end of a period of 30 years of pedological investigations, which were carried out in that territory by Dutch soil scientists. In view of the future in which scientists and other workers will continue to promote agricultural development in the territory of West Irian, it seemed useful to make available a review of the soilscientific work that had been done so far and to summarize the main forthcoming results and conclusions.

The desirability of writing this review in English was based on the consideration that all soil surveys and soil-fertility studies have been put on record in the Dutch language in the form of type-written internal reports, which were distributed on a limited scale to Government officials and to some scientific institutes in the Netherlands (see ANNEX II).

Two main periods of soil research in West Irian may be broadly distinguished, viz. the period from 1932 to 1950 and the period from 1950 to October, 1962.

During the first period all soil surveys were conducted by pedologists of the Institute of Soil Research at Bogor (Indonesia), which was a department of the Government Agricultural Research Organisation in the former Netherlands East Indies. Most surveys of that period date back to the years before the second World War and they were carried out, mainly by soil surveyor F. A. WENTHOLT, on reconnaissance scales varying from $1: 100.000$ to $1: 250.000$.

In those days the territory of West Irian was far less accessible than it is now, as air transport was entirely lacking so that each soil survey, departing from Bogor, became a cumbersome and time-consuming expedition. 
Moreover, topographical base maps on scales $1: 100.000$ were available only for some parts of the vast area of 416.000 square kilometres, whereas the use of aerial photographs for soil-survey purposes was not yet practised.

Consequently, soil maps had to be based predominantly on terrestrial observations and measurements, which were often confined to the nearest vicinity of the measuring traverses because of such natural obstacles as dense jungle, rough topography, or swampy conditions of the terrain. By the end of 1950, a total area of about 500.000 ha covering 14 locations had been surveyed.

Another aspect marking this first period of soil studies was the method of soil analysis used by the aforementioned Soil Research Institute at Bogor. This method was not used in West New Guinea in later years so that soil-analysis figures produced before and after 1950 are not readily comparable.

It is worth mentioning that the results of all soil surveys carried out before the second World War are reviewed by vaN BEUSECHEM (1947) in a non-published report; a brief summary, unfortunately without maps, was published in the Dutch language (VAN BEUSECHEM, 1948). His work was rewritten and supplemented by vaN BAREN in 1950 with a summary in English. It was not published until three years later as a separate chapter of the three-volume standard work edited by KLEIN (1953) which contains all other scientific information on the Territory available at that time.

The second period of pedological research started in 1950 with the appointment of a Government Soil Scientist, F. C. VAN LoENEN, who established a Bureau of Soils in the Territorial capital of Hollandia (now: Kota Baroe). The initial growth and working capacity of the Bureau was slow, due to a lack of funds, staff and appropriate equipment. Nevertheless, each year a steadily increasing area was surveyed. It was not until 1956, however, that the actual survey technique could be improved and both the capacity and the accuracy of the surveys could be increased by the introduction of aerial photo-interpretation methods. Likewise, the somewhat provisional laboratory methods of the previous years were revised, rigidly standardized and maintained unchanged from 1956 onward. During these years some 6.000 soil samples were collected and described according to the standards set by the U.S. Soil Survey Manual, whereas more than 35.000 granular, chemical and mineralogical analyses were carried out. More particulars about the growth and operations of the Bureau of Soils in Hollandia are recorded by REYNDERS (1961).

In the course of this second period of about 12 years, another 1.300 .000 ha of land were surveyed on various mapping scales, which ranged from reconnaissance scales up to $1: 63.360$ to detailed mapping scales of $1: 20.000$ and larger.

As several areas surveyed during the first period on small reconnaissance scales had to be resurveyed in greater detail during this second period, the actual area of land covered by soil surveys by the middle of 1962 may be estimated at 1.250 .000 ha which is $3 \%$ of the total land surface of West Irian.

\subsection{Objectives and principles of soil research}

Throughout the history of soil research in West Irian, the guiding motive for soil surveys has always been the immediate need for local information about soil suitability in any one place where agricultural activities were planned or happened to be undertaken. Most of the pre-war surveys were inspired by the purpose to find "empty" alluvial areas suitable for the establishment of estates and agricultural settlements which could serve also as resettlement centres for small farmers and peasants from over-crowded Java. 
Figure 1 


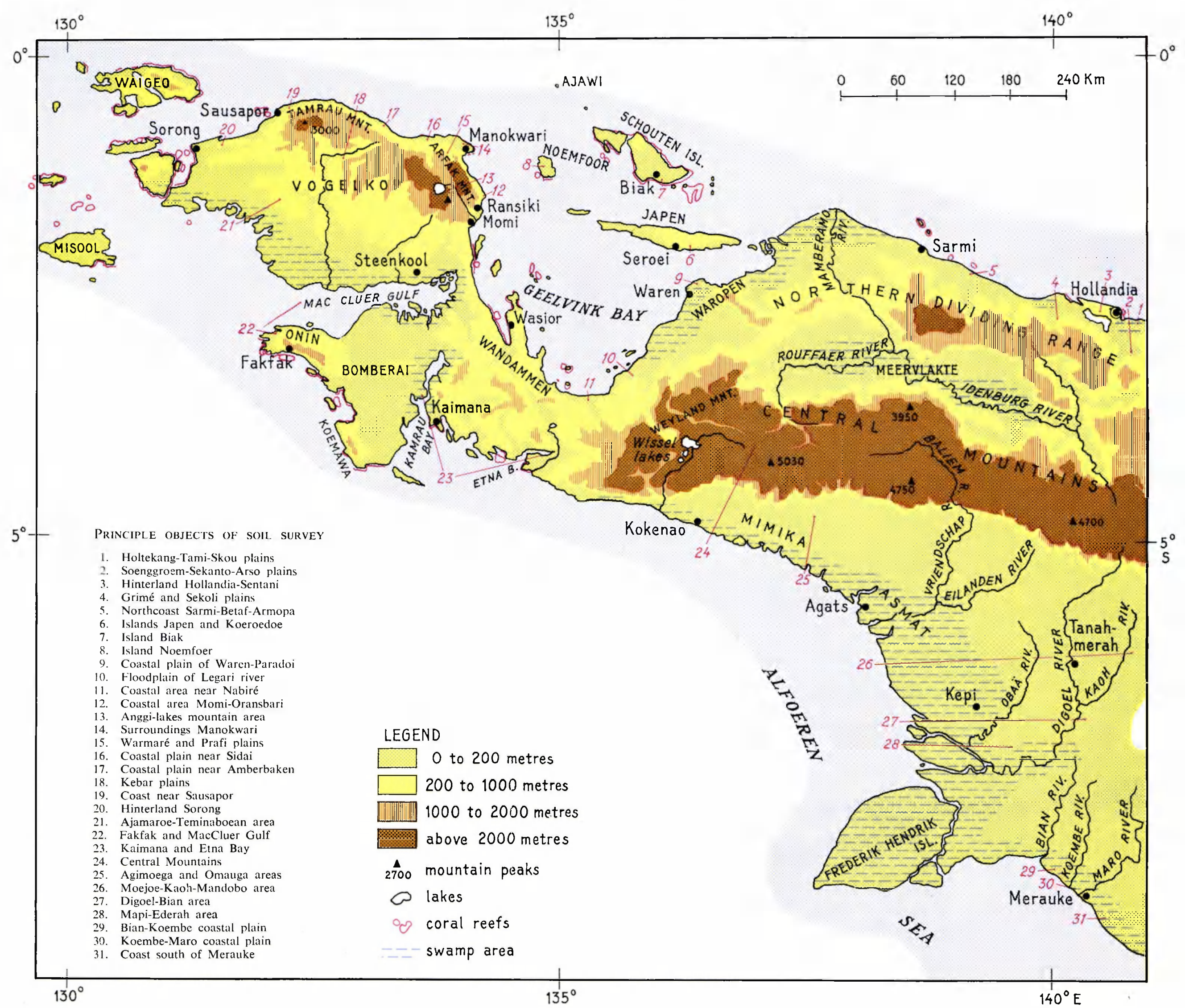

Fig. 1. Topographic map of West Irian with indication of the objects of soil survey 
After the war, the more or less haphazard search for suitable, uninhabited areas was continued but was aimed, mainly, at resettlement of Papuan communities now living in areas with poor or limited land resources, such as exist in the Moejoe and Ajamaroe areas and in the Central Highlands. In addition, soil surveys had to be carried out wherever the growth and progress of rural communities called for new areas to be opened up. Appraisal of the land for its capacity to carry food crops and such newly introduced cash crops like cacao, coffee, nutmeg and rubber was invariably the ultimate goal of all soil investigations.

As the Government held the view that, at the present stage of Papuan rural development, all native agricultural enterprise had to be conducted at a low level of finantial and physical effort, only land that did not require elaborate or costly measures of drainage, levelling, terracing, soil management or the use of fertilizers, was deemed suitable.

Therefore, the activities of the Bureau of Soils were mainly confined to the search for and the study of areas that were expected to be relatively flat, dry, fertile and accessible. In exceptional cases, soil surveys were aimed at the appraisal of land suitable for large-scale agricultural development schemes, as was e.g. the case in the southern part where a large mechanized rice scheme was intended to be started.

With these directives and principles of soil research on hand, it is evident that large parts of this vast Territory - 13 times the land area of the Netherlands, with a scattered population of less than 700.000 - have never been visited by professional soil scientists. These parts do not seem to hold any immediate promise for agricultural enterprise because of their remoteness, swampiness, rough topography, infertility or high altitude, as far as can be deducted from the evidence provided by other sources of basic information.

Although this incidental and localized approach to the inventory of West Irian soils was the inevitable consequence of the urgency to gather a maximum quantity of practical information about soils in preferential localities with the given narrow limits of time, funds and staff, it is still highly regrettable that because of this approach the soil investigations have been lacking the necessary context which should be based on a thorough, systematic fundation and consistant nomenclature.

Our soil surveyors had to rush from one unknown spot to the other instead of being able to descend from general to detailed information and to design the systematic background of the local surveys on the strength of regional reconnaissance surveys. It is thus rather difficult to construct presently a satisfactory overall-picture from our incomplete fragments of information.

\subsection{Evaluation of available soil maps}

Today, these fragments are provided by some seventy different soils maps, which have been produced in the course of years on various scales and by successive surveyors whose personal judgements and techniques also have varied. The thirty localities which have been covered by these surveys are indicated in FIG. 1. The maps are accompanied by reports which contain classified information for each locality about topography, geology, morphology, hydrology, vegetation, climate, soil types and laboratory investigations.

These original reports are enumerated in ANNEX II.

However useful these seventy soil maps may be for local reference, they do not form together a coherent system of pedological information. They are often somewhat unbalanced in one way or the other, their legends are not standardized and 
their mapping units are of different weight and character. On the earlier maps, soil types or soil series were used as the smallest, primary mapping units. Because the interrelationship between these units was often not properly understood, through lack of surveyability, they could not easily be grouped into categories of a higher order. Likewise, extrapolation of soil boundaries, beyond the actually sampled area along the traverses, was risky through lack of information so that the soil maps remained unbalanced.

During the last six years, on the other hand, the application of aerial photo interpretation induced the primary use of much larger, physiographic mapping units which were clearly visible on the aerial photograph as well-defined land systems. Land systems are natural landscapes with a specific pattern of rocks, landforms, soils and vegetation. They reflect the presence of certain soil complexes. By means of actual field work, these soil complexes are further analyzed and subdivided into separate soil groups. However, many of our soil maps constructed in this manner stood midway between a land-classification map and a soil map, simply because the agricultural purpose of the survey and the available time in the field restricted the actual soil mapping and sampling to those physiographic mapping units where suitable soils could be expected. Unsuitable land classes like swamps, marshland, steep or dissected country, karst areas and the like, remained largely unanalysed. Consequently, these types of soil maps are also unbalanced from a soil surveyor's point of view.

\subsection{Possibledesign of a regional soil map}

From the foregoing retrospection it will be understood that the construction of a regional soil map of West Irian on a useful scale and based on accurately measured characteristics of the soils involved is impossible at present. Even on a small scale of $1: 5$ million, the construction of such a map is hardly feasible.

Soil profiles have been studied, described and analysed in only $3 \%$ of the total area and almost exclusively in alluvial, level terrains. Extension of this information by means of interpolation and extrapolation, in order to arrive at a soil map of the whole, is not justified. To this end, soil studies should have been made at random over the entire range of parent materials, landscape elements and altitudal regions.

The best approach would have been, if time, funds and personnel had allowed for, to divide the Territory into a number of large morphological units such as the Central Mountains, the Great Lake Plain, the Northern Dividing Range, the North Coast, the Waropen Coast, the Wandammen Coast, the Vogelkop and Bomberai Peninsulas, the Kaimana Coast, the Mimika Coast and the Digoel-Fly Depression or Southern Plains.

For each of these areas, a stock-taking by a team of specialists could have been realized through a careful study and analysis of aerial photographs, followed by field surveys in a number of key areas. Such an approach would have yielded a complete land classification, whereas a natural system of soil classification with corresponding nomenclature, valid for the whole of the Territory could have been developed. In the Australian, more developed part of New Guinea, this way of land classification is practised already for many years and carried out by survey teams from the Australian mainland.

All there remains to do at present, is to familiarize the reader in the course of the following chapter with general conditions of soil genesis and to review briefly the principal general aspects of climate, vegetation, topography and parent material 
which play a predominant role in soil genesis in this country. From this information a rough pattern of genetic soil groups will emerge which will serve the reader as a general background for the further discussion of soils and soil suitabilities in the investigated localities.

\section{Environmental conditions of soil genesis}

\subsection{Cli m a t e}

As far as soil genesis is conditioned by the prevailing climatic factors of the present era, we are mainly concerned with temperature and rainfall.

New Guinea as a whole is characterized by a hot and humid climate. The average annual temperature in the lowlands lies around $26^{\circ} \mathrm{C}$ with small monthly fluctuations. At an altitude of $1500 \mathrm{~m}( \pm 5000 \mathrm{ft})$ this average annual temperature will drop to around $10^{\circ} \mathrm{C}$, whereas the permanent snowline is found somewhere between 4300 and $4500 \mathrm{~m}(14.000-15.000 \mathrm{ft})$ above sea level.

Precipitation in West Irian is generally heavy, as is shown on the provisional map in FIG. 2a. In the greater part of the Territory the annual rainfall is more than

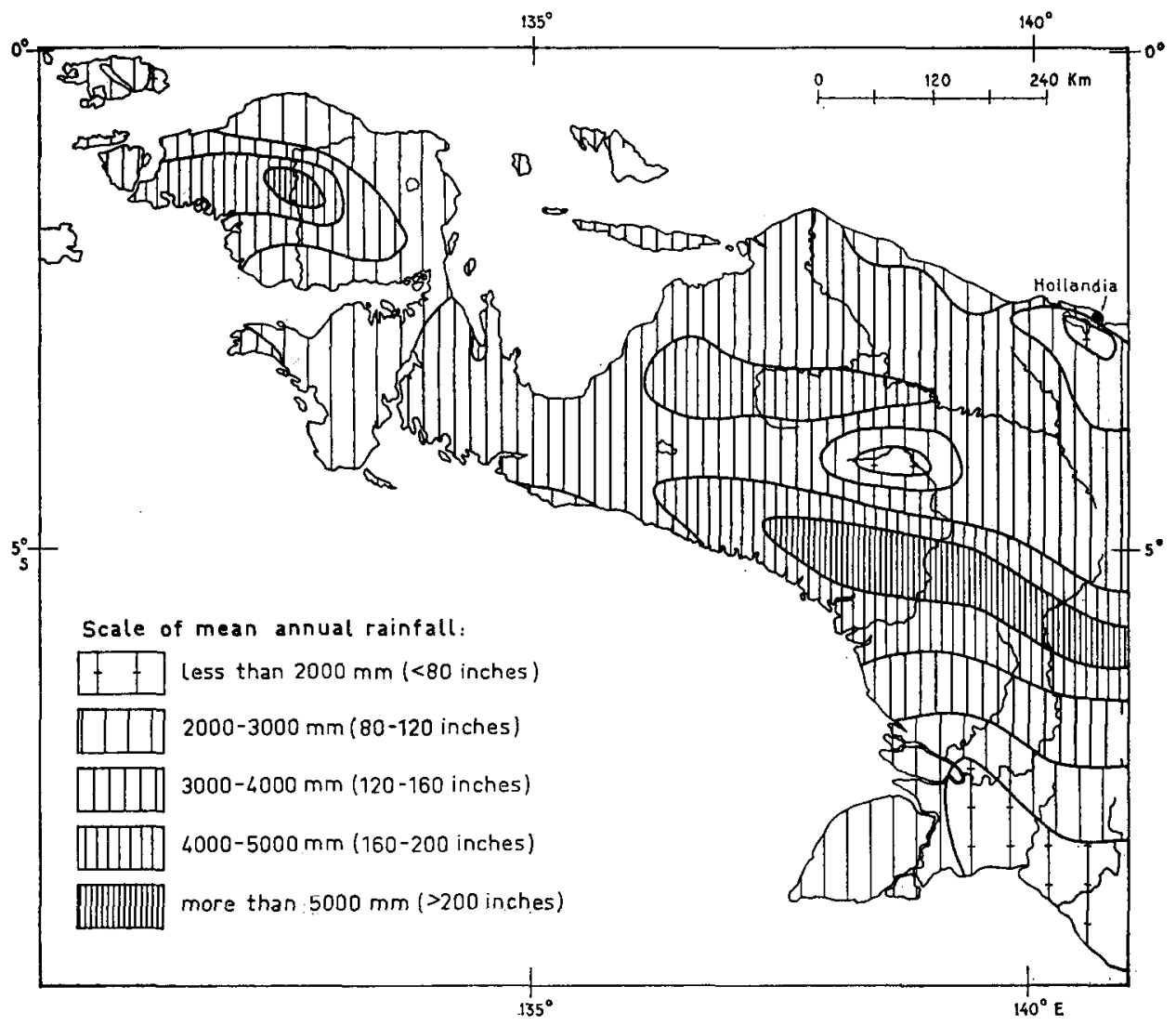

FIg. 2a. Annual rainfall in West Irian

Neth. J. agric. Sci., Vol. 11 (1963) No. 4 (August) 


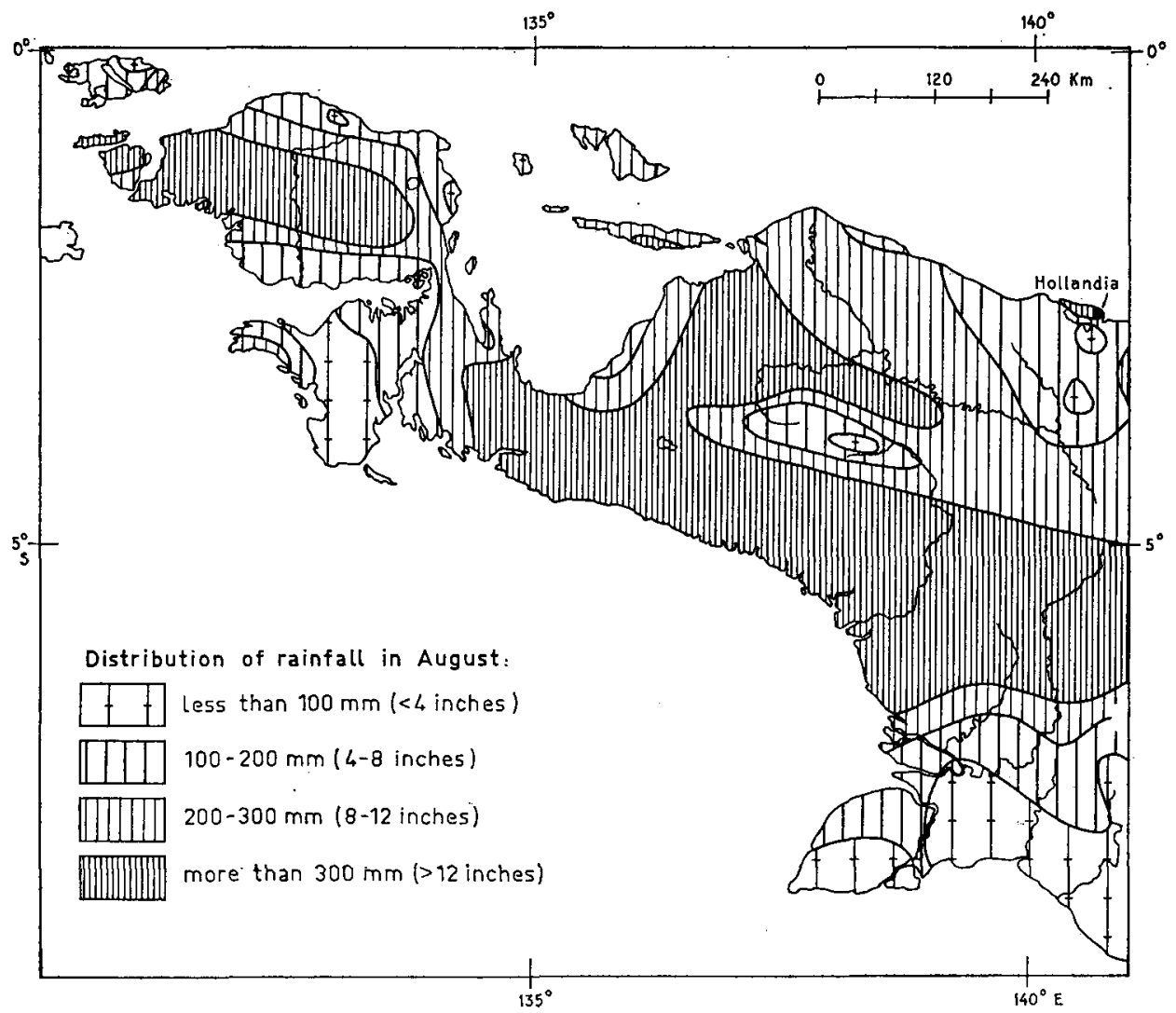

FIg. 2b. Rainfall distribution in West Irian during August

$3000 \mathrm{~mm}$ ( 210 inches), although this figure may even be twice as high in certain parts of the country, e.g. in the southern border region of the Central Highlands. Areas with an annual rainfall of less than $2000 \mathrm{~mm}$ (80 inches) are rare, with the exception of the farmost southern part where a pronounced dry season is induced by the Australian monsoon.

The annual rainfall is generally well distributed over the seasons so that in the greater part of the country the rainfall in the driest month will never be less than $200 \mathrm{~mm}$ ( 8 inches). In certain parts in the west, the centre and the south of the Territory monthly rainfalls below the $8^{\prime \prime}$-level do occur. Restricted localities within these areas will even suffer from droughts during a few months of the dry monsoon in which less than $100 \mathrm{~mm}$ of rain may fall. On the map in FIG. $2 \mathrm{~b}$ these areas are indicated for the month of August, which is one of the driest months.

Summarizing the above data, it may be stated that outside the restricted areas with a really dry season, the majority of the soils in West Irian is subject to continuous and excessive leaching. Likewise, it may be said that as far as soil fertility is concerned, shortage of soil moisture is seldom a limiting factor in plant production. 
Consequently, this aspect of soil fertility has never received major attention in our field and laboratory work.

In the second chapter of KLEIN's Handbook more detailed information about the climate is presented, based on data up to 1950. Supplementary information, published after 1950, is listed in the literature reference (ANNEX I).

\subsection{Vegetation}

At least $90 \%$ of the country is covered with dense tropical forest. The remainder is covered with tree savannas, grass savannas and grass swamps, due mainly to anthropogenic influences. Repeated burning for hunting purposes promote the permanent character of this fire-climax vegetation.

Comparing from the air the general picture of the forest cover in western and eastern (= Australian) New Guinea, the difference is almost dramatical as the incidence of grass wilderness is far greater in the Australian part, due to the forest being destroyed by the devastating process of shifting cultivation of the larger population (three million).

Outside the drier monsoonal areas, the predominant climatic-climax vegetation on the free-draining soils of the lowlands and of the highlands below an altitude of $1500 \mathrm{~m}$ is formed by the moist, evergreen, tropical rain forest. This type of forest contains a great variety of timber species in the lower, middle and upper canopies. Its composition is intricate and may differ widely from one locality to another. Little is known about the ecological factors, including soil conditions, which determine the actual pattern of the ever-changing composition of the rain forest.

Conversely, the botanical make-up of forest associations within the domain af the rain-forest formation has not yet provided much of a clue to the understanding of corresponding soil types. Forest associations as well as individual tree species that are recognizable on aerial photographs are often found to cover a wide range of parent materials and soil types. Topography and related drainage conditions are believed to be the overruling ecological factors in most instances.

The dense forest growth on free-draining soils should not be mistaken as a proof of high soil fertility. Our surveys revealed that in several instances dense forest was found to grow on almost sterile soil types, such as senile oxysols, pure quartzitic sands and limestone soils, which have developed on almost pure calcium carbonate rock. Various investigators (HARDY, 1936; MILNE, 1937; NYE and GreENLAND, 1960) have stressed the point that under mature forest the nutrients are maintained in a nearly closed cycle from which few nutrients are lost in the drainage. The thriving force of this cycle is the uppermost humic surface soil, which holds most of the tree roots and contains all the nutrients needed for a continuous growth of the forest. Once this precarious equilibrium between soil and forest is disturbed by the destruction of the forest and loss of the top soil, the regeneration of forest and soil is hard to achieve. Only if the soil is left fallow for a period from 20 to 30 years, and in the absence of fires, will the forest be able to develop fully again on the poorer soil types.

On the poor-draining soils of the lowlands and uplands the relationship between certain forest associations and corresponding soil conditions is often more evident and in many instances can be deducted from aerial photographs. Going farther inland from the sea shore, a systematic succession of natural forest communities is often encountered, according to the gradually changing conditions of swampiness and brackishness of the terrain. 
Departing from a Barringtonia or a Casuarina beach vegetation or, from a mangrove forest along the shore line, a transitory zone of decreasing brackishness is formed by the Nipah palm forest (Nipa fructicans) under semi-brackish conditions of the swamp, and the Nibung palm forest (Oncosperma filamentosa) in swamp areas that are only occasionally polluted with brackish water at high spring tide. Behind this transitory zone the peat forest may follow or, the various types of swamp forest in the rain-fed, permanently (or semi-permanently) inundated areas that cover large parts of the lowlands. The Sago palm forest (Metroxylon spp.), which is found up to an altitude of $900 \mathrm{~m}$, is typical for West Irian.

In the semi-arid regions in the south, the swamp forest will dry up completely during a few months of the year and then be exposed to fires. Here, a special fireclimax forest known as "gelam" forest (Melaleuca leucadendron) has developed. Most of these communities and their intermediate forms are easily recognizable on aerial photographs when using a photo scale of $1: 20.000$ or larger.

The sub-alpine or montane forest and the alpine forest, which natural communities are found above the approximate altitude of $1500 \mathrm{~m}$, will remain undiscussed, as mittle soil research has been carried out in these high altitudal regions.

Interesting data about flora and vegetation are given by vaN STEENIS (1950) and Beversluis (1950). After 1950, supplementary data haven been collected and compiled in type-written reports by the Government Forestry Section.

\subsection{Topography and hydrology}

Two thirds of the land surface are occupied by steep, badly dissected hilly country and almost inaccessible, rough mountain regions with altitudes reaching up to $5000 \mathrm{~m}$ as can be seen from FIG. 1.

Due to orogenetic and tectogenic movements during the Plio-Pleistocene era, we are dealing at present with young landmasses with very immature geomorphic features. Excessive relief is characteristic of all highlands. Gently rolling and undulating country, typical of mature landforms, hardly occur in West Irian. The mountainous landmasses of the territory can be roughly divided into three major mountain ranges, which stretch in a general northwestern to southeastern direction and are seperated from each other by synclinal depressions which are made up of swampy basins and plains.

The northernmost anticlinal range is formed by the mountains of the Schouten and Japen islands, the Koenamba islands north or Sarmi, and by the Cyclope Mountains near Hollandia which reach up to an altitude of $2200 \mathrm{~m}$. This range extends across the eastern border as the Bougainvillea Mountains. The second anticline is formed by the Northern Dividing Range, which runs from the dissected hilly country near the Waropen coast, via the Van Rees, Gauttier and Bonggo Mountains towards the Torricelli Mountains in the Australian half of New Guinea.

The third or Central Mountain Range forms the actual backbone of New Guinea and extends eastwards from the islands of Waigeo, Batante and Salewati with summits of $1000 \mathrm{~m}$ altitude, through the northern parts of the Vogelkop Peninsula, where altitudes of around $3000 \mathrm{~m}$ are reached in the Tamrau, Arfak and Lina Mountains. In the northern part of the peninsula the trend changes to southwest and then to south through the narrow $70 \mathrm{~km}$ wide isthmus, where the minimum altitude of passes is still $400 \mathrm{~m}$.

The mountains continue to the south but the main range adopts an easterly trend 
and forms the Central Mountains with altitudes increasing from $2000 \mathrm{~m}$ in the west to rugged, snow-capped mountains reaching an altitude of $5000 \mathrm{~m}$. The abrupt rise of the Central Mountains from the lowlands to the north and south is clearly visible on the topographic map in FIG. 1.

Most of the lowlands are poorly drained. They receive considerable amounts of water from the adjacent highlands but their natural drainage along the surface is often impeded by slight levees along the rivers and slightly elevated-ridges of sand and silt along the shore. Quite often sand bars are formed off-shore, in front of the river outlets so that a free discharge of flood waters is obstructed.

Thus extensive swamp areas are found in the Central Basin (Great Lake Plain), north of the Dividing Range along the north coast, the Mamberamo delta, and Waropen coast, around the MacGluer Gulf, Arguni Bay and all along the coastal belt south of the Central Mountains.

In the southern part of the last-mentioned area, swamps will dry up during the dry monsoon, as was mentioned already in the preceding paragraph. Even in the highlands, including the Central Mountains, the more or less level terrains are often poorly drained and will remain wet throughout the greater part of the year, as the discharge of the abundant rainfall along the ground surface is impaired by the microrelief of the terrain. In such level and wet terrains, it has been often observed that the tangle of thick roots of the forest vegetation, which protrude several inches above the ground, may add considerably to the obstruction of the free drainage of rainwater.

From the above information it may be deducted that soil genesis is greatly affected by the extreme topographical and hydrological conditions marking the country. As far as topographical conditions are concerned, the excessive relief is the cause of continuous rejuvenation through truncation or sheet erosion on slopes and through deposits of erosion products in areas of sedimentation. Therefore, essential landscape elements playing an important role in soil genesis (and consequently also in soil mapping), are slopes, alluvial fans, hillfoot colluvia, terraces, floodplains, inland basins and coastal plains. Likewise, the hydrological conditions, of which flooding and drainage are the most important aspects, determine the frequency and duration of waterlogging and leaching imposed on soils in level terrains.

\subsection{Parent materials}

Most parent materials from which the soils are developed through genetic processes are, on the average, of a poor mineral composition. There is only a limited number of relatively small areas in the country where soils are formed on parent materials derived from igneous rock, such as basalt, andesite, gabbro, diabase, tuff, granite and diorite. These small remnants of Tertiary and pre-Tertiary volcanism are mainly found in the northern parts of the Vogelkop Peninsula, the island Japen and near Hollandia. Isolated outcrops of igneous rock are also found in the Northern Dividing Range and the Central Mountains, as is shown on the geological sketch map in FIG. 3. It should furthermore be emphasized that recent volcanism, though still existing in the eastern half of New Guinea, is absent in the western part of the island, so that there is no rejuvenation of soils through a fall-out of volcanic ashes or dust. Most of the highlands in the country, making up two thirds of the total land area, consist of Tertiary and Pleistocene sedimentary rock of either calcareous or quartzitic composition. Besides, all types of limestones, marls, shales, conglomerates, 
sandstones and mudstones make up the bulk of these parent rocks. Sedimentary rock of the Mesozoic and Paleozoic eras occurs sparsely (see FIG. 3) and comprises the same range of rocks. In addition, metamorphic sedimentary rock like gneiss, schist and slate also belong to these eras. Large areas in the Central Mountains, the Central Vogelkop and other places still are "terra incognita".

The principal sources of geological information up to 1951 are mentioned in the literature references given by VAN BEMMELEN (1953) in his review of Geology and Mining, contained in KLEIN's Handbook. A new and up to date synopsis of geological data will be published by the Royal Geological and Mining Society of the Netherlands (see VISSER and Hermes, 1962) in the early course of 1963.

The larger part of the sedimentary rocks, except the corallogene limestones, consist of mineralogical components which have gone through more than one geological cycle of weathering and impoverishment, quartz being their major mineral. Even in soils that have developed on calcareous rock, the mineralogical analysis of their sand fractions reveals a predominance of quartz, which mineral formed the primary and main impurity in the calcareous matrix of the parent material. Incidentally, it should be mentioned that extensive karst areas may be found where limestones consist of almost pure calcium carbonate.

The alluvial soils of plains, basins, valleys and fans, which together make up one third of the total land surface, have developed on deposits of erosion products originating in the highlands. Their parent materials are therefore mainly quartzitic sands, silts, silty loams and silty clays, besides the coarser-textured materials like gravels and boulders.

Locally, the young alluvial parent materials are calcareous when marls, calcareous sandstones, etc., occur in the highlands. The better parent materials are found in alluvial areas where rivers have brought material of a mixed mineralogical composition because they cut their way in the highlands through a variation of rocks.

When dealing with alluvial soils, it is the texture, mineralogical composition and the resulting chemical properties of the parent materials that mainly determine the course of pedogenesis and provide the mapping criteria.

\subsection{General pattern of genetic soil types}

From the foregoing paragraphs it follows that the geographical distribution of the various genetic types of soil in the Territory does not follow a regular and systematic pattern of distinct belts, zones or regions, as the principal causes of soil genesis vary considerably from one locality to the other and occur in various combinations. Therefore, land surfaces often present a mosaic of very different types of soil. Of the three factors, climate, topography and parent material, the climate is the steadiest. The high temperature of the tropical lowlands decreases with higher altitudes in a regular way, whereas the prevailing heavy and continuous rainfall is only modified to an appreciable extent by monsoonal influences in the southernmost part of the country.

Speaking in terms of MARBUT's genetic system of soil classification (1936), it may be assumed that soils belonging to his category of "pedocals" do not occur in this country, "pedalfers" being the ruling category, as continuous leaching and high carbon-dioxide production will eventually remove the lime from the solum.

As far as the influence of climate and vegetation on soil genesis is concerned, it could be expected that in the tropical lowlands the zonal latosolic types and in the elevated highlands the zonal, light-coloured podzolic types of soil predominate. 


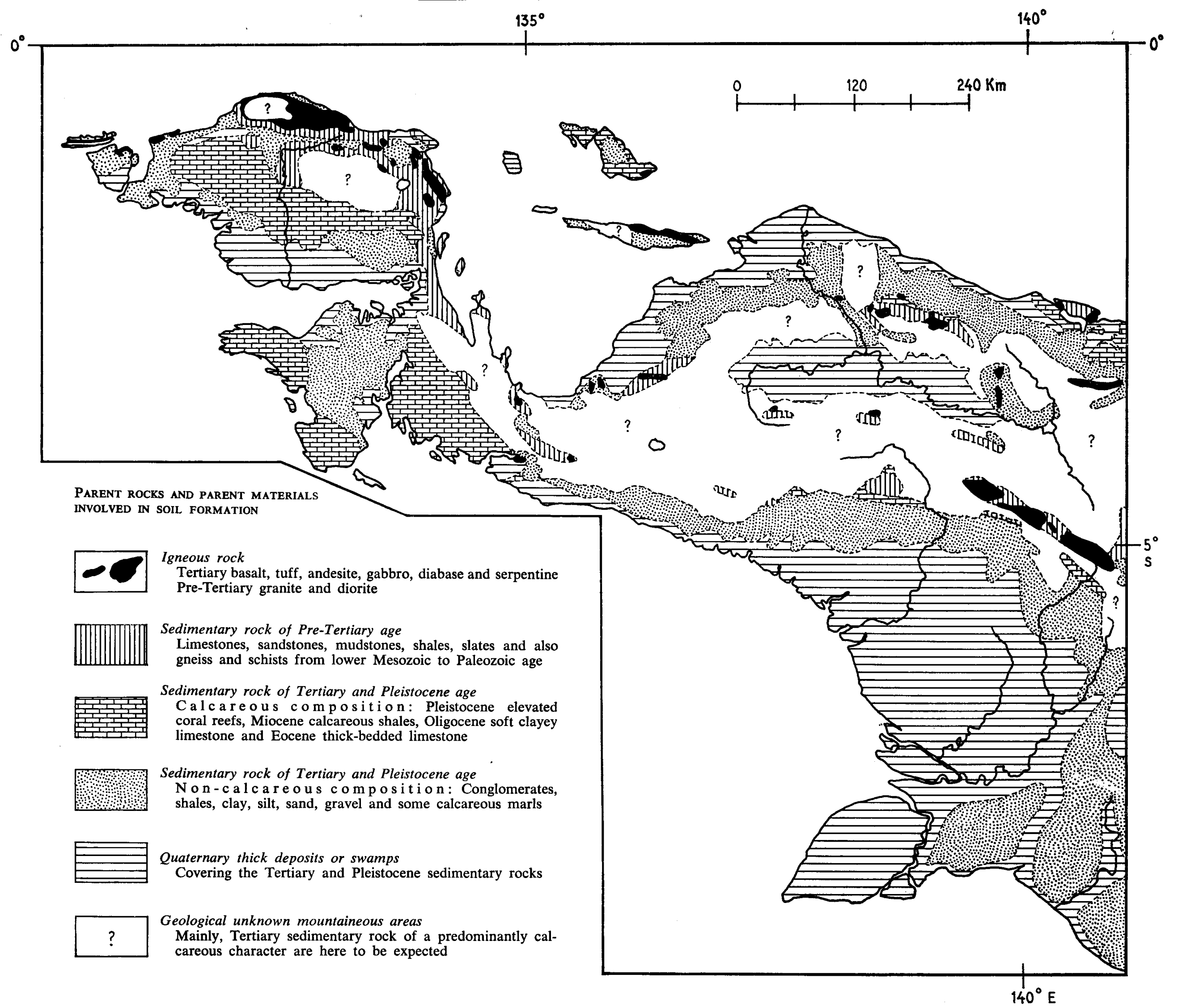

FIG. 3. Geological scetch map of West Irian 
These terms refer to the corresponding suborders of the American Classification System developed by Thorp and SMIтH (1949). The line at an altitude of $1000 \mathrm{~m}$, shown in FIG. 1, may for convenience's sake be regarded as an arbitrary borderline between the two zonal regions. However, in many areas the occurrence of azonal and intrazonal types of soil is a rule rather than an exception.

Azonal types of soil, such as lithosols, all sorts of truncated soils and young alluvial soils frequently occur, because the immature geomorphology of the country is not yet in balance with the strong forces of erosion, causing continuous rejuvenation of soil through erosion in the uplands and through sedimentation processes in the lowlands.

Intrazonal soils are also numerous in West Irian, due to the preponderant influence of some local factor, such as poor drainage or extraordinary parent material, over the normal effect of climate and vegetation.

In marshes, swamps, seep areas, flood plains and coastal plains, hydromorphic soils of various types are prevalent. In these waterlogged areas, phytomorphic soils may develop under certain conditions which are lack of oxygen primarily, and low temperatures as far as the highland peats are concerned.

Various transitional forms between zonal, azonal and intrazonal types of soil may develop on a given parent material. In broken terrain, successive phases of erosion and sedimentation, combined with changing conditions of drainage and aeration, often result in a catenary sequence of soils that are marked by good aeration, shallowness and bright reddish colours of the solum in the higher parts as against deeper, yellowishgrey soils with poorer internal drainage in the lower parts of the terrain. The numerous alluvial fans fringing the foot of hills and mountains represent a classic example of a catena marked by amorphic coarse-textured soils along the slopes and finer-textured amorphic, hydromorphic or even phytomorphic soils at the bottom.

The intrazonal soils induced by extraordinary properties of the parent material are also well presented in the Territory by all types of calcimorphic soils at one end and by acid, leached parent materials like quartzitic sands, loams and silts at the other end.

The calcimorphic types could be divided into soils developing on relatively pure calcium carbonate rock and those which develop on admixtures of mineral and calcareous material. The first group, that of real limestone soils, is well defined and the few types are conditioned mainly by altitude, slope and the permeability of the underlying limestone. They are found in karst areas in which thick layers of limestone dissolve without leaving much residue behind. The mature, decalcified soil which forms a deep solum only in the terrain depressions consists of dehydrated ironoxides and a calcium-aluminium phosphate as described by ScHroo (1963). On the steeper slopes this soil type will not reach maturity.

The second group of calcimorphic soils that develop on calcareous material of a mixed composition, shows pattern of soil types that follow the intricate irregularity of textural and chemical variations initially present in the sedimentary parent material. The mineralogical make-up and texture of the non-calcareous particles together with the actual percentage of calcium carbonate in the topsoil and subsoil define the properties and classification of these soils.

In the humid tropical lowlands podsolic types of soil may develop on parent materials that are acid and void of bases. Here, the occurrence of red and yellow podsolic soils is believed to be more frequent than the occurrence of the zonal latosolic soils. Likewise, there are parent rocks on which initially a latosolic type of 
soil developed which became lateron subject to podsolization.

Intrazonal soils of the halomorphic sub-order are practically absent. In the southern coastal area, Schroo (1961) has described a soil type that meets the requirements characteristic of a non-alkali saline soil only during the dry season; however, shortly after the onset of heavy rains the saline character of the soil will disappear. Real saline soils are found in the littoral zone along the coast, but these soils are amorphic and belong to the order of azonal soils. The generalized pattern of genetic soil groups, as described in this paragraph, will sufficiently fulfill the purpose of its presentation. Perhaps, it may be visualized more clearly if the data comprised in the maps of FIGS. 1 and 3 are put together so as to form a genetic soil map. We abstain, however, from actually drawing this soil map because it might suggest a certain degree of precise and established knowledge which, in fact, is not available.

\section{Soil suitability, soil quality and methods of analysis}

\subsection{Soil suitability}

Soil suitability depends chiefly on the combined effect of the three parameters: relief, drainage and the potential soil quality (kind of soil).

In the preceding chapter, the reader has been made familiar with the prevailing unfavourable aspects of relief and drainage. He should bear in mind, throughout the following account, that almost everywhere in the highlands the hazards of erosion are accelerated as soon as the protecting forest cover is removed for the purpose of agricultural land use. In addition, it should be remembered that in most level terrains, either in the highlands or in the lowlands, the hazards of flooding or prolonged waterlogging are always present. For these reasons, soil suitabilities in terms of present land use are more limited than would be expected in such a large country as West Irian. Even if due allowance is made for the application of relatively simple technical measures of land improvement, the range of suitable soils is not appreciably increased as only rather small areas of land can be improved in this way under the conditions prevailing in New Guinea. This circumstance is aggravated by the fact that the majority of local tribes and settled rural communities is not yet accustomed to the great efforts required by drainage and erosion-controlling measures.

In this respect an exception must be made for the Marind tribe in the south and the Dani tribe in the Central Highlands, where the people use an ingenious system of ditches and raised planting beds for the growing of their subsistence crops in poorly drained areas. In all other instances where the agricultural extension service of the Government has not yet succeeded in changing the natural methods of native land use, the population invariably resorts to the wasteful system of shifting cultivation, for which purpose each tribe or community reserves large areas of land. In addition, much larger areas of more or less unsuitable land are reserved for hunting purposes. No measures to prevent erosion (terracing, contour planting, ground covers, etc.) are taken so that the fertile topsoil and ashes on the newly burnt and planted clearings are washed down the slopes as soon as the first rains fall.

It is obvious that land hunger already exists in a few, more densely populated areas. The need for suitable soils will inevitably increase rapidly as the population continues to grow and the necessity to cultivate cash crops in addition to the normal food crops is felt to an increasing extent.

Below, and particularly in chapter 4, we will discuss mainly soil suitabilities in terms of present and durable land use which is exercised by properly trained small- 
farmers. In this connection, most soils in broken or dissected country are classified as unsuitable, while all soils in areas that are subject to temporary flooding or to marshy conditions are also considered unsuitable for present use.

Soil suitabilities in terms of future use, including improvement of the land by means of expensive agricultural engineering or soil-management practices involving high skill, much labour and technical equipment, will be considered only in connection with large agricultural development schemes that were already in preparation or initiated by the previous Government.

An inventory of soil suitabilities in terms of future use will therefore have to be left to succeeding soil scientists who come to work in this territory.

\subsection{Soil quality}

When judging soil suitabilities in the areas where relief and drainage do not present great difficulties, soil quality will be the deciding parameter. Soil quality is inferred from taxonomic and analytical characteristics of the soil profile. It includes the organic-matter contents, textures and structures of the various horizons which determine the value of important physical properties of the soil. It also comprises the mineralogical make-up of the soil and the complex of chemical potentialities with respect of plant nutrition, which faculties are commonly referred to with the more specific name of "soil fertility".

Soil quality, and soil fertility in particular, depends for the larger part on the primary properties of the parent material. Especially in younger soils, as all our alluvial soils are, we may expect that their qualities are closely related to those of the parent materials on which they develop.

Although in many countries young aluvial soils are synonymous with fertile soils, it should not be overlooked that in West Irian many of the alluvial soils are not so fertile because the sediments on which they form are primarily of a poor mineralogical composition. The cursory survey of parent materials, presented in paragraph 2.4., suggests that, as a whole, no great expectations may be entertained of the chemical and mineralogical qualities of the soil-forming materials in this country.

This fact is somewhat obscured by the circumstance that under dense forest cover an apparently high level of soil fertility is maintained in the organic matter-containing surface horizon, which level does not bear a proportional relation to the poorness of the sub-horizons. This unequal distribution of plant nutrients over the various horizons of the solum has specific consequences with respect to the interpretation of soil-fertility analyses. This aspect will be dealt with in the next paragraph.

\subsection{Sampling technique used in soil-fertility appraisal}

The sampling technique of representative soil profiles in aid of normal soil-survey work does not need any special comment, as this has always been done by our soil surveyors in the usual way.

By taking a representative sample from each horizon, one has to assemble the analytical features of these various horizons in order to arrive at an over-all appraisal of the soil's fertility. In doing so, rarely the individual thickness of each sampled soil layer is accounted for in the over-all appraisal. This point would deserve little attention when dealing with soil profiles that contained a fixed number of horizons within a certain depth of soil, each being of equal thickness. Assuming that such a solum was also homogeneously rooted by a given tree crop, the amalgamation of the analyses made for each horizon would offer no problem, as the 
arithmetical average of all analyses would provide the correct basis for appraisal. However, the thickness of successive horizons vary widely and so do the soil profiles within the same soil series. Moreover, some plant nutrients are more concentrated in one horizon and more leached from others. Even in case of dealing exclusively with surface horizons, it is evident that the thickness of these horizons will alter the interpretation of analytical data. A surface layer, six $\mathrm{cm}$ thick and rich in plant nutrients may be as valuable as another surface layer of $12 \mathrm{~cm}$ that contains only half the amount of nutrients. Especially on poor soils the thickness of relatively fertile, organic surface layers is an important factor. Therefore, it is a rather risky task to compare, in a country-wide survey, the fertility of variously developed profiles and to interprete correctly the mass of incomparable analytical data of a wide range of different soils.

In order to facilitate the comparison of soils with respect to their capacity of supporting perennial tree crops, the author introduced a special way of sampling in addition to the normal sampling of profile horizons. Departing from the approximation, that the immediate nutrition of such tree crops depend primarily on the nutrient content of the upper $25 \mathrm{~cm}\left(10^{\prime \prime}\right)$ of topsoil and secondarily on the supplementary nutrient content of the underlying soil layer of $25 \mathrm{~cm}$, we used to sample each of these two layers separately. To this end a vertical slice of about one inch thick and six inches wide was cut, after the $\mathbf{A}_{00}$ - and $\mathbf{A}_{0}$-layers had been removed.

For each soil series a number of such rapid samplings were carried out and each sample was analysed separately. The resulting averaged analysis, which was calculated for each of the two soil layers, provided a reliable standard set of analytical evidence. In combination with the profile description and general terrain conditions a clear conception of soil quality and suitability could thus be obtained.

A limited number of these standard analyses will be presentey in ANNEX III of chapter 4 , when dealing with soil suitabilities in various localities.

\subsection{Methods of analys is}

For a better understanding of the analytical data presented in the original reports and in the following chapter, a brief explanation may serve the reader for guidance. In support of the taxonomic description of soil types, a limited series of laboratory determinations was carried out on almost all samples that were collected in the field. This group of routine analyses comprised the determination of texture class, soil reaction, organic-matter percentages and, in addition, free calcium carbonate, total soluble salts, chlorine and sulphate concentrations according to indications. A mineralogical analysis of the sand fraction $200-50 \mu$ was carried out for subsoil horizons whenever such evidence was required to differentiate between soil series.

\section{Texture}

Since 1956, textural class names of soil series have been based exclusively on the outcome of mechanical analysis, the same grain-size limits of soil separates and the same class names being used as indicated in the U.S. Soil Survey Manual (1951). All analyses are related to suspensions of primary particles, as pseudo-textures were elliminated through pre-treatment of the soil suspensions with $\mathrm{H}_{2} \mathrm{O}_{2}$ and diluted $\mathrm{HCl}$. In the earlier surveys, textural class names were based on field appraisal, whereas in the laboratory the samples were pre-treated with ammonia only and two more clay separates were included in the analyses. Therefore, textural names and analyses before and after 1956 are not entirely comparable. 


\section{Organic matter}

An evaluation of the organic-matter content was obtained by the determination of readily oxidizable Carbon by the rapid method of Walkley and Black. This method is satisfactory for a general orientation, as long as no reducing inorganic compounds are present in the sample. The Carbon content thus determined is assumed to present $76 \%$ of the actual total Carbon percentage. The humus factor for this method is tentatively assumed to be approximately 2,25 , although this factor must be subject to variation when dealing with a wide range of soil types like we did.

In TABLE 1 an arbitrary quantitative scheme of the aforementioned soil factors is presented.

TABLE 1.

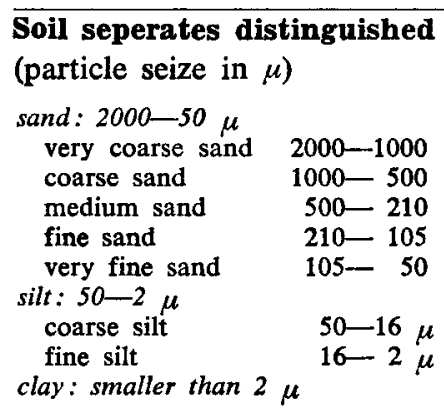

\section{Soil reaction}

(pH-normal)

(soil : water $=1: 21 / 2$ )

$9,0-8,0$ very highly alkaline

$8,0-7,5$ highly alkaline

$7,5-7,0$ alkaline

7,0 neutral

$7,0-6,5$ slightly acidic

$6,5-6,0$ acidic

$6,0-5,5$ markedly acidic

$5,5-5,0$ highly acidic

$5,0-4,5$ very highly acidic

\section{Textural class names}

\section{(U.S. Soil Survey Manual)}

1. coarse-textured soils : sands and loamy sands

2. moderately coarse-textured soils : sandy loams

3. medium-textured soils: loams, silty loams and silts

4. moderately fine-textured soils : clay loams; sandy- and silty clay loams

5. fine-textured soils: clays; sandy- and silty clays

Free carboonates

( $\mathrm{CaCO}_{3}$ percentage)

(Scheibler's gas-volumetric method)

$$
\begin{aligned}
0-0,5 & \text { traces } \\
0,5-2,5 & \text { low } \\
2,5-5,0 & \text { medium-low } \\
5,0-10 & \text { medium } \\
10-15 & \text { medium-high } \\
15-25 & \text { high } \\
25-50 & \text { very high } \\
50-100 & \text { extremely high }
\end{aligned}
$$

\section{Carbon percentage} (method Walkley and Black)

$0,00-0,25$ extremely low

$0,26-0,50$ very low

$0,51-1,00$ low

$1,01-1,50$ medium-low

1,51-2,00 medium

2,01-2,75 medium-high

2,76-3,50 high

$3,51-4,50$ very high

4,51-7,50 extremely high

(carbon recovery $76 \%$ )

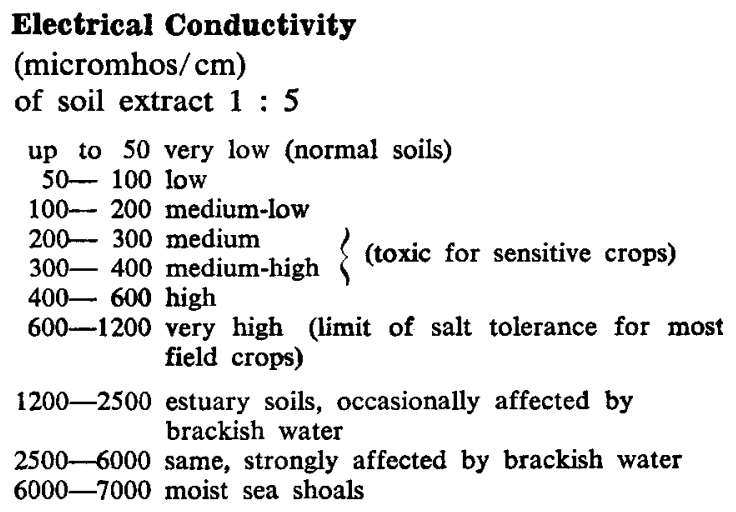


TABLE 2 shows a similar series of laboratory determinations which were carried out, in addition to the first group, for the assessment of soil fertility. These analyses comprise the determination of :

- easily soluble cations in $3 \%$ acetic acid extract $(10 \mathrm{~g}: 400 \mathrm{cc})$.

- easily soluble phosphate in 0,002 $\mathrm{N}$ sulphuric acid (Truog) $(2 \mathrm{~g}: 400 \mathrm{cc}$ ).

- total phosphate and potash through wet digestion with Fleischmann acid.

In more detailed and special studies on soil fertility, the cation-exchange capacity, total exchangeable bases and saturation degree were also determined whereas also other types of extractions were used, which will be left undiscussed.

The author is well aware of the limitations which adhere the use of a standard method of extraction for the evaluation of soil fertility, when dealing with a wide range of soils and various types of crop.

However, when prospecting an almost unknown territory, there is hardly an alternative. This approach offers at least the advantage of measuring soil qualities in a uniform way and thus allows of a global comparison of various soil types.

TABLE 2.

\section{Easily soluble cations}

(oxides in $\mathrm{mg} / \mathrm{kg}$ air-dry soil)

extraction: $10 \mathrm{~g}$ soil in $400 \mathrm{cc} 3 \%$ acetic acid

$$
\mathrm{CaO}
$$

extremely low $\ldots$
very low $\ldots \ldots \ldots$

medium-low .... 1500-2000

medium $\ldots \ldots \ldots .2000-2500$

medium-high ..... 2500-3000

high .......... $3000-4000$

very high $\ldots \ldots \ldots 4000-5000$

extremely high

above 5000

free $\mathrm{CaCO}_{3}$

$\mathrm{MgO}$

below 100

$100-200$

$200-400$

$400-600$

$600-800$

$800-1000$

$1000-1200$

$1200-1500$

above 1500

Mg-salts
Easily soluble $\mathbf{P}_{2} \mathbf{O}_{5}$

Truog extraction

$\mathrm{P}_{2} \mathrm{O}_{5}$
$0-5$
$5-10$
$10-20$
$20-40$
$40-60$
$60-80$
$80-120$
$120-180$
above 180
Ca-phosphates

\section{Total analyses}

(percentages)

\begin{tabular}{|c|c|c|c|}
\hline & digestion with & schmann acid & extraction with $25 \% \mathrm{HCl}$ \\
\hline & $\mathrm{P}_{2} \mathrm{O}_{5}$ & $\mathbf{K}_{2} \mathrm{O}$ & $\mathrm{P}_{2} \mathrm{O}_{5}+\mathrm{K}_{2} \mathrm{O}$ \\
\hline extremely low ... & below 0,025 & below 0,10 & below 0,010 \\
\hline very low $\ldots \ldots \ldots$ & $0,025-0,050$ & $0,10-0,20$ & $0,010-0,020$ \\
\hline low $\ldots \ldots \ldots \ldots$ & $0,050-0,075$ & $0,20-0,30$ & $0,020-0,040$ \\
\hline medium-low & $0,075-0,100$ & $0,30-0,40$ & $0,040-0,050$ \\
\hline medium $\ldots \ldots \ldots$ & $0,100-0,125$ & $0,40-0,50$ & $0,050-0,060$ \\
\hline $\begin{array}{l}\text { medium-high } \ldots \ldots \\
\text { high } \ldots \ldots \ldots \ldots \\
\text { very high } \ldots \ldots \ldots \\
\text { extremely high } \ldots \ldots\end{array}$ & $\begin{array}{l}0,125-0,175 \\
0,175-0,250 \\
0,250-0,350 \\
\text { above } 0,350\end{array}$ & $\begin{array}{r}0,50-0,75 \\
0,75-1,00 \\
1,00-1,50 \\
\text { above } 1,50\end{array}$ & $\begin{array}{l}0,060-0,080 \\
0,080-0,100 \\
0,100-0,150 \\
\text { above } 0,150\end{array}$ \\
\hline
\end{tabular}

The acetic acid extraction (two times 30 minutes shaking, with $24 \mathrm{hrs}$ interval) This extraction for the estimation of easily soluble Calcium, Magnesium and Potas- 
sium has proved a very useful and convenient method and a reliable measuring routine for a wide range of soils. The method has been used for Potassium by other investigators of tropical soils and crops, and thus yields the advantage of certain established standards of evaluation. The method also provides a good cross-check on the figures for free-lime content by the Scheibler method, as the concentrations of available $\mathrm{CaO}$ are linear correlated with percentages of $\mathrm{CaCO}_{3}$. Above values of $4000-5000$ p.p.m. CaO, free lime is almost sure to be present. The presence of free $\mathrm{MgCO}_{3}$ is also deductable from the correlation factor. The presence of free Magnesium salts, including carbonates, is apparent from very high $\mathrm{MgO}$-figures in the extract.

It should be noted that the standards of evaluation given in TABLE 2 refer to the full range of concentrations that may be encountered in a great variety of soil types. They do not bear a direct relation to the levels of adequacy with respect to crop requirements.

However, it may be assumed that levels of $1500-2000$ p.p.m. $\mathrm{CaO}$ and a level of $150-200$ p.p.m. $\mathrm{MgO}$ for both surface soil and subsoil are adequate for the nutrition of most perennial crops.

As far as potash is concerned, the author is inclined to indicate a level of 250 p.p.m. $\mathrm{K}_{2} \mathrm{O}$ as being adequate for such crops as cacao or coffee, provided that the percentage of total potash is well above 0,5 .

The determination of potash levels of adequacy for various crops on all sorts of soils is complicated. Agricultural production in West Irian has not yet provided sufficient field evidence to establish rules in much detail.

\section{Truog extraction}

This method, used for the estimation of easily soluble phosphates, also provided a reasonably good measuring routine when dealing with unsaturated soils, although the implications of phosphate fixation on these soils do not warrant a reliable interpretation, especially not when low values are measured. In that instance, additional information is needed, which is obtained from the total-phosphate percentage.

A low Truog-value, combined with a low total-phosphate percentage is a true indication of acute phosphate shortage in the soil.

A low Truog-value, combined with a medium-high total-phosphate percentage is less easy to interpret, although the author is inclined to rely on the figure for total phosphate when tree crops are involved.

On the other hand, high Truog-values can be relied upon when dealing with nonalkaline soils. It has been observed that high Truog-values invariably turn up when even traces of apatite are found in the (finest) sand fraction of a soil. The tiny fragments of apatite present in the sand and silt fractions give off considerable quantities of easily soluble phosphate but they do not show up in the second decimal of the total-phosphate percentage.

Extremely high Truog-values in the range of 1000 p.p.m. $\mathrm{P}_{2} \mathrm{O}_{5}$ and higher, are encountered in certain soils which develop on hard corallogene limestones and correspond with total-phosphate percentages above 0,35 . These soils may even contain as much as 10 to $25 \%$ total phosphate, as has been described by ScHroo (1962).

\section{Extraction with $25 \% \mathrm{HCl}$}

This extraction was used in the earlier days for the estimation of total potash and phosphate. The method has not been used since 1950 . 


\section{A N NEX I}

L I T ER A T URE (cited or consulted)

Anon.

Beusechem, D. vaN

BAREN, F. A. VAN

Bemmelen, R. W. van

Beversluis, A. J.

Birrel, K. S., and Grange

BraAK, C.

Brzesowsky, W. J.

Chang, A. T., and SHERMAN

Edelman, C. H.

Gelder, J. K. VAN

GoGH, F. VAN

HARDY, F.

HeldRING, O. G.
1943 Weather Summary. Hydrographic Office U.S. Navy Dep. 1943. Publ. No. 276, Naval Air Pilot, New Guinea Area.

1959 Meteorologie Nederlands Nieuw Guinea; Voorlopige Atlas. Issued by Royal Dutch Navy.

1958 Regenval in Ned. Nieuw Guinea. Publ. No. 2.

1959 Duration of sunshine. Publ. No. 4.

1960 Diurnal variation of rainfall. Publ. No. 7.

1960 Extreme waarden der regenval van een antal plaatsen in Ned. Nieuw Guinea. Meded. No. 1.

1958-1960 Issued by Meteorological and Geophysical Bureau at Hollandia.

1947 Overzicht van de morfologische, geologische, klimatologische gesteldheid van Ned. Nieuw Guinea, zomede beschrijvingen van een veertiental gebieden waarvan de gegevens ten aanzien van bodemgesteldheid en landbouwmogelijkheden bekend zijn. (unpublished report).

1948 Korte bijdrage tot de kennis van de bodemgesteldheid en de landbouwkundige waarde van een veertiental geëxploreerde gebieden in Ned. Nieuw Guinea. Landbouw. No. 20:210229.

1953 Bodem. See KLEIN, Part II, Chapter III, 67-105 (Eng. summary).

1953 Geologie en Mijnbouw. See KLEIN, Part I, Chapter VI, 259-284 (Eng. summary) and VII, 285-310 (Eng. summary).

1949 The Geology of Indonesia. Vol. I A. Martinus Nyhoff, The Hague.

1953 Bossen. See KLEIN, Part II, Chapter VII, 276-356 (Eng. summary).

1939 Chromium in soils of Western Samoa and Niue Isl. N.Z. J. Sci. \& Tech. 21, 91 A--95 A.

1953 Klimaat. See KLEIN, Part II, Chapter II, 42-66 (Eng. summary.

1962 Podsolic and hydromorphic soils on a coastal plain in the Cameroon Republic. Neth. J. agric. Sci. 10, 145-153.

1953 The nickel content of some Hawaiian soils and plants and the relation of nickel to plant growth. Hawaii Agr. Expt. Sta. Tech. Bull. No. 19.

1950 Soils of the Netherlands. North Holland Publishing Comp., Amsterdam.

1910 Verslag van een geologische verkenning van de Mamberamo rivier op Nieuw Guinea. Jaarb. Mijnwezen in Ned. Indië, 1910.

1953 Kleine landbouw en kolonisatie. See KLEIN, Part II, Chapter IV, 106-190 (Eng. summary).

1936 Some aspects of tropical soils. Trans. 3rd Int. Congr. Soil Sci., Oxford, 1935. Vol. 2, 150-163.

1909 De Zuidkust van Nieuw Guinea. Jaarb. Mijnwezen in Ned. Indië, 1909.

1911 Verslag over Zuid Nieuw Guinea. Jaarb. Mijnwezen in Ned. Indië, 1911 . 
Klein, W. C. et al.

Loth, J. E.

Marbut, C. F.

Milne, G.

MoHR, E. C. J., and

F. A. van Baren

MolengraAF, H. J.

NYE, P. H., and

GREENLAND

Patchet, E. L., and HATTINGER

PolaK, B.

RAPPARD, T. W., and VAN ROYEN

REYNDERS, J. J.

Robinson, W. O.

ScHROO, H.

Steenis, C. G. G. J. van

TAN, K. H., and J. VAN SCHUYLENBORGH

THORP, J., and

L. R. SMITH
1953 Nieuw Guinea, de ontwikkeling op economisch, sociaal en cultureel gebied in Nederlands en Australisch Nieuw Guinea. Staatsdrukkerij en Uitgeversbedrijf, The Hague.

1924 Verslag van Geologische en mijnbouwkundige verkenningen in het Noordelijk en Oostelijk deel der Vogelkop. Jaarb. Mijnwezen in Ned. Indië, 1924.

1936 Soils of the United States. U.S. Dept. of Agric.

1937 Essays in applied pedology. E. Afr. Ag. J. 3.

1954 Tropical Soils. Interscience Publishers Ltd., London.

1957 De Kebarvlakte. (non-published report 18-7-1957).

1960 The soil under shifting cultivation. C.A.B. Techn. Comm. No. 51).

1937 Reconnaissance of the Manokwari area. Deport N.N.G.P.M. 14-8-1937.

1938 Report on the geology reconnaissance of the Islands of Biak and Soepiori. Report N.N.G.P.M. 9-5-1938.

1950 Occurrence and fertility of tropical peat soils in Indonesia. Contrib. Gen. Agric. Res. Station. Bogor. No. 104.

1959 Enige notities over de vegetatie in het gebied der Wisselmeren. Nove Guinea. 10. No. 2.

1961 Soil survey in Netheriands New Guinea. Comm. Neth. Soil Survey Inst. Auger and Spade. XI.

1960 Voorlopige mededeling van het agrogeologisch onderzoek in het Sterregebergte. Tijdschr. Kon. Ned. Aardr. Genootsch. LXXVII. No. 2.

1961 Some remarks about shifting cultivation in Neth. New Guinea. Neth. J. agric. Sci. 9, 36-40.

1961 The landscape in the Maro and Koembe district. Comm. Neth. Soil Survey Inst. Auger and Spade. XI.

1962 A brief report on the occurrence of peat in Netheriands New Guinea. Comm. Neth. Soil Survey Inst. Auger and Spade. XII.

1935 Chemical studies of infertile soils derived from rock high in magnesium and generally high in chromium and nickel. U.S. Dep. of Agric. Techn. Bull. No. 471.

1959 Acute zinc deficiency observed in cacao on certain soil types in Netherlands New Guinea. Neth. J. agric. Sci. 7, 309-316.

1960 A presentation of leaf analytical data of cacao, obtained from a fertilizer trial in Netherlands New Guinea. Neth. J. agric. Sci. 8, 93-97.

1961 Some pedological data concerning soils in the Baliem Valley, Netherlands New Guinea. Nieuw Guinea Studien. 301-307.

1961 Data on the salinization of a coastal soil in the monsoonal rice area of Southern New Guinea. Neth. J. agric. Sci. 9, $231-248$.

1963 A study of highly phosphatic soils in a tropical karst region of the humid tropics. Neth. J. agric. Sci. 11, 209-231.

1953 Vegetatie en Flora. See KLEIN, Part II. Chapter VI, 218275. (Eng. summary).

1961 Classification and genesis of soils over acid volcanic material. Neth. J. agric. Sci. 9, 41-54.

1949 Higher categories of soil classification: order, suborder, and great soil group. Soil Sci. 67, 117-126. 
TWERENBOLD, E. F.

VISSER, W. A., and HERMES

ZWIERZYCKI, J.
1956 Geological survey of the Manokwari area. Report N.N.G.P.M. No. 410.

1962 Geological results of the exploration for oil in Netherlands New Guinea. Verh. Kon. Ned. Geol. \& Mijnbouwk. Genootschap. Geologisch serie XX, spcial issue.

1921 Verslag geologische en mijnbouwkundige onderzoekingen in een gedeelte van Noord Nieuw Guinea. Jaarb. Mijnwezen in Ned. Indië, 1921.

1927 Geologische overzichtskaart $1: 1.000 .000$ met toelichting. Jaarboek Mijnwezen in Ned. Indië, 1927.

1930 Geologische overzichtskaart van Ned. Indische Archipel op schaal $1: 1.000 .000$. Jaarb. Mijnwezen in Ned. Indië, 1930. 


\section{LIST OF ORIGINAL REPORTS OF SOIL RESEARCH 1}

1. Holtekang-Tami-Skou plains

1.1. B. SCHLETTE (1960): Verslag van de bodemkundige verkenning van het Holtekang-TamiSkou areaal.

2. Arso plains

2.1. W. J. VAN SOELEN (1946) : Terreinverslag van de bodemkundige kaartering van de Soenggroem-Arso vlakte.

2. Hintenland Hollandia-Sentani-Depapre

3.1. F. A. WENTHOLT (1932): Tournee verslag van de doorsteek Hollandia-Pim-SentanimeerDepapre.

3.2. H. TE RIELE \& F. A. WENTHOLT (1932) : Verslag bodemkundig onderzoek van de doorsteek Hollandia-Pim-Sentanimeer-Depapre.

3.3. F. H. N. RAZOUX SCHULTZ (1958): Verslag van een onderzoek naar voor tuinen geschikte terreinen in de omgeving van Hollandia-Haven.

3.4. F. C. VAN LOENEN (1950): Verslag van een vluchtig onderzoek in het sago-moeras van Kota-Radja.

3.5. W. J. VAN SOELEN (1952): Terreinverslag van de bodemkundige opname van een deel der vlakte van Kota-Radja.

3.6. J. J. REYNDERS (1955) : Enkele voorlopige mededelingen omtrent de grondgesteldheid van de dalkom bij Reinauwen.

3.7. J. P. ANDRIESSE (1956): Morfologie en bodemgesteldheid van het proefstationsareaal te Kota Nica.

3.8. W. J. VAN SOELEN (1952): Terreinverslag van een bodemkundige opname van een deel der Sentani-vlakte.

3.9. W. J. VAN SOELEN (1953): Een bodemkundige opname van een terrein in de nabijheid van het Sentani vliegveld.

3.10. W. L. P. J. MOUTHAAN (1953) : De gronden in het heuvelgebied rondom het Sentanimeer.

3.11. B. SCHLETTE (1960): Rapport betreffende een vluchtige verkenning van een terrein ten zuiden van het Sentanimeer i.v.m. mogelijkheden voor veeteelt.

4. Plains of Grimé and Sekoli rivers

4.1. F. A. WENTHOLT (1939) : Voorlopig verslag van de kaartering van de Grime-Sekoli vlakte.

4.2. W. J. VAN SOELEN (1953): Bodemkundig verslag van het Sokoata-Sermo gebied.

4.3. W. J. VAN SOELEN (1951): Kort verslag van een bodemkundige opname nabij Genjem.

4.4. F. H. N. RAZOUX SCHULTZ (1958): Verslag van een bodemkundige opname van het oostelijk deel Grimé vlakte.

4.5. H. SCHROO (1961) : Analyse-rapport ener bodembemonstering in het oostelijke deel der Grimevlakte.

1 A complete set of these original reports is kept in the archives of :

Department of Agriculture and Agricultural Research Station in West Irian.

Library "Ministry of the Interior", Plein 1, the Hague, Netherlands.

Library "Soils Department of the State Agricultural University", Duyvendaal, Wageningen, Netherlands.

Library "Soils Department of the Royal Institute for the Tropics", Mauritskade, Amsterdam, Netherlands. 
5. Northcoast Sarmi-Betaf-Armopa

5.1. W. J. VAN SOELEN (1951): Terreinverslag van de verkenning van de Tor-Biër vlakte.

5.2. W. J. VAN SOELEN (1952): Terreinverslag van de bodemkundige verkenning van de kuststrook tussen de Biër en de Wiroe.

5.3. G. HEKSTRA en B. SCHLETTE (1960) : Verslag van de bodemkundige opname van de kuststrook tussen Betaf en Armopa.

5.4. W. J. VAN SOELEN (1958) : Een bodemkundige opname van de Orai-Woské-Tor arealen.

6. Coastal plains of the island Japen

6.1. F. H. N. RAZOUX SCHULTZ (1958) : Verslag van een bodemkundige verkenning van arealen aan de zuidkust van Japen en het eiland Koeroedoe.

6.2. J. J. REYNDERS (1956): Korte verslagen betreffende de vlakten van Seroei en Korenbobi.

6.3. F. H. N. RAZOUX SCHULTZ (1957) : Kort verslag van de verkenning der Areaepi vlakte.

6.4. F. H. N. RAZOUX SCHULTZ (1955): Kort verslag van de bodemkundige opname van de Randawaja vlakte (Analyse rapport van 1954).

7. The is land Biak

7.1. F. H. N. RAZOUX SCHULTZ (1959): Verslag van een bodemkundige verkenning van een deel van het eiland Biak.

7.2. G. HEKSTRA (1961): Bodemkundige verkenning van de streek tussen Siabes en Wardo op Z.W. Biak.

7.3. G. HEKSTRA (1961): Verslag van de bodemkundige kaartering van het Agathis-boscomplex op Oost Biak.

8. The island Noem foer

8.1. F. H. N. RAZOUX SCHULTZ (1954): Kort verslag van de bodemkundige verkenning van het eiland Noemfoer.

9. Coastal plain Waren-Paradoi

9.1. J. VALETTE (1961): Een bodemkundige verkenning van het kustgebied tussen Waren en Paradoi.

10. Floodplain Legari river

10.1. F. A. WENTHOLT (1940): Voorlopig verslag van de bodemkundige kaartering langs de Legari rivier.

11. Coastal area near Nabiré

11.1. R. VAN AART en J. C. G. SCHWAN (1962): Een bodemkundige verkenning van het achterland van Nabiré.

12. Coastal area Momi-Oransbari

12.1. F. A. WENTHOLT (1934) : Rapport bodemkundig onderzoek der kustvlakte bij Momi.

12.2. F. A. WENTHOLT (1938): Verslag van het bodemkundig onderzoek van de vlakte der War Ransiki en haar omgeving.

12.3. J. J. REYNDERS (1954): Veldgegevens Ransiki, Wariti, Oransbari en Andai met bodemgebruikskaart Ransiki-delta.

12.4. W. J. VAN SOELEN (1951): Verkenningsrapport Oransbari.

13. Mountain area of Anggi-lakes

13.1. F. A. WENTHOLT (1934): Voorlopig verslag van de kaartering van het Angi-Angi gebied.

14. Surroundings of Manokwari

14.1. F. A. WENTHOLT en M. v. d. VOORT (1940) : Verslag van de kaartering van het achterland van Manokwari. 
14.2. W. J. VAN SOELEN (1947) : Kort terreinrapport van de Manggoapi en west-Wosi vlakte.

14.3. F. W. J. VAN ES (1949) : Verslag van een bodemkundige verkenning van het Amban-gebied.

14.4. J. J. REYNDERS (1957) : Kort verslag van een bodemkundig onderzoek in de omgeving van Manokwari.

14.5. H. SCHROO (1957) : Analyserapport betreffende cacao-gronden nabij Manokwari (en Ransiki).

14.6. W. J. VAN SOELEN en B. SCHLETTE (1958): Verslag van een bodemkundige opname van Amban en Andai nabij Manokwari.

14.7. H. SCHROO (1959): Analyserapport grondmonsters van het proefstationsareaal te Amban.

14.8. TH. DEMOTEKAY (1960): Verslag van een bodemdiepte kaartering op het Amban plateau.

15. Floodplains of Warmare and Prafi rivers

15.1. J. J. REYNDERS (1954): Korte samenvatting van de grondgesteldheid van de Prafi-vlakte.

15.2. F. H. N. RAZOUX SCHULTZ (1959): Verslag van de bodemkundige verkenning van de Warmare-vlakte.

15.3. G. HEKSTRA en R. H. DE BOCK (1961): Verslag van de bodemkundige kaartering van de Prafi-vlakte.

16. Northcoast near Sidai

16.1. W. J. VAN SOELEN (1955): Terreinverslag van de bodemkundige opname van de Sidaivlakte.

17. Northcoast near Amberbaken

17.1. F. A. WENTHOLT (1933): Voorlopig bodemkundig verslag van het landschap Amberbaken.

18. Kebar plains

18.1. J. J. REYNDERS and H. SCHROO (1958) : Verslag van een bodemkundige kaartering der Kebarvlakte.

19. Northcoast near Sausapor

19.1. B. SCHLETTE (1962): Verslag van een bodemkundige kaartering in de omgeving van Sausapor.

20. Hintenland of Sorong

20.1. F. A. WENTHOLT (1933): Voorlopig verslag van de bodemkundige kaartering der WarSamsonvallei en het omringende berg- en heuvelland.

20.2. F. W. J. VAN ES (1948): Verslag van een bodemkundige verkenning van het achterland van Sorong.

20.3. B. SCHLETTE (1961): Kort verslag van een tweetal onderzoekingen in de omgeving van Sauka nabij Sorong-Remoe.

21. Ajamaroe-Teminaboean area

21.1. J. J. REYNDERS and F. RAZOUX SCHULTZ (1958): Verslag van een bodemkundige verkenning van het Ajamaroe gebied.

21.2. J. VALETTE and B. SCHLETTE (1960) : Kort voorlopig verslag van een voortgezet bodemkundig onderzoek in het Ajamaroe gebied.

21.3. H. SCHROO and W. L. P. J. MOUTHAAN (1960) : Voorlopig verslag van een oriënterende potproef met mais, ter beoordeling van Ajamaroe-grond als fosfaatmeststof.

21.4. J. A. HOEKENDIJK (1962): Bodemvruchtbaarheidsrapport betreffende twee kaarteringsobjecten in het Ajamaroe gebied.

22. FakFak and coast of $\mathrm{MacCluer}$ Gulf

22.1. G. HEKSTRA and B. SCHLETTE (1959): Verslag van de bodemkundige opname in de omgeving van FakFak, op Poeloe Argoeni en bij Kaimana.

Neth. J. agric. Sci., Vol. 11 (1963) No. 4 (August) 
23. Argoeni and Etna bays

23.1. D. VAN BEUSECHEM (1947): Information about objects 22 and 23 are compiled by $D$. VAN BEUSECHEM from various exploration reports written by foresters and agricultural officers. No real soil surveys have been carried out in this surrounding.

24. Central Mountains

24.1. J. J. REYNDERS and M. F. HOFMAN (1959) : Een bodemkundige en landhuishoudkundige verkenning van het Wisselmeren gebied en de Kamoevlakte.

24.2. H. SCHROO (1960): Een bodemvruchtbaarheidsonderzoek van de gronden om het Paniaimeer.

24.3. H. SCHROO (1958) : Bodemkundig verslag van een oriëntatie bezoek aan de Baliem.

24.4. J. J. REYNDERS (1958) : Kort verslag van een bezoek aan de Sibil vallei.

25. Agimoega-, Akaro- and Omauga area

25.1. G. HEKSTRA and B. SCHLETTE (1960): Verslag van de bodemkundige kaartering van een terrein gelegen bij de samenvloeiing van de Akimoega en de Akaro, alsmede van de verkenning van een terrein aan de Omauga bij Belikmakkema.

25.2. H. SCHROO (1958) : Analyserapport van 16 ingezonden grondmonsters uit de Mimika.

26. Moejoe-Kaoh-Mandobo area

26.1. F. H. N. RAZOUX SCHULTZ (1954) : Kort verslag van de bodemkundige verkenning van het gebied tussen de Kao- en Moejoe rivieren.

26.2. J. TH. WHITE (1928): Bodemkundige adviezen inzake ingezonden grondmonsters van het Boven-Digoel gebied.

27. Digoe1-Bian area

27.1. G. HEKSTRA and J. VALETTE (1961): Verslag van een bodemkundige verkenning in het Digoel-Bian gebied.

27.2. W. L. P. J. MOUTHAAN (1962) : Bodemvruchtbaarheidsrapport van het Digoel-Bian gebied.

28. Mapi-Ederah area

28.1. W. J. VAN SOELEN (1957): Verslag van een bodemkundige opname in het Mapi gebied.

28.2. H. SCHROO (1958) : Bemestingsadvies inzake cacao in het Mapi-gebied.

29. Bian-Koembe coast

29.1. W. J. VAN SOELEN (1954): Terreinverslag van de bodemkundige opname van het kustgebied tussen de Toran-, Koembe- en Marau-rivieren.

29.2. F. H. N. RAZOUX SCHULTZ (1955) : Kort verslag van de bodemkundige opname van het kustgebied tussen de Toran- en Bian rivieren.

29.3. P. BURINGH and J. SCHILSTRA (1954): Een bodemkundige luchtfoto-interpretatie van een deel der zuidkust van Nieuw Guinea.

29.4. F. C. VAN LOENEN (1954): Bodemkundig verslag van het polderareaal "Koembe".

29.5. J. P. ANDRIESSE (1954) : Kort verslag bij de vegetatie-associatie schetskaart van de proefpolders te Koerik.

29.6. J. J. REYNDERS (1955) : Enkele voorlopige mededelingen aangaande de grondsoorten in het landbouwproefbedrijf "Koembe".

29.7. J. J. REYNDERS and J. P. ANDRIESSE (1957): Kort verslag betreffende de detailkaartering van bovengronden in het proefpolderareaal van het rijstbedrijf "Koembe".

29.8. H. SCHROO (1957) : Rapport bodemanalytische gegevens betreffende de bovengronden van het proefpolderareaal "Koembe".

29.9. H. SCHROO and W. L. P. J. MOUTHAAN (1957/58): Verslag der potproeven nr. 1, 2, 3 en $3 a$ met rijst, betreffende onderzoek boven- en ondergronden van het proefpolderareaal Koembe. 
AN INVENTORY OF SOILS AND SOIL SUITABILITIES IN WEST IRIAN. I

29.10. H. SCHROO and W. L. P. J. MOUTHAAN (1958) : Analyserapport inzake het onderzoek naar de physische kenmerken van "dragende" en "niet dragende" gronden in de Noordpolder van het rijstproefbedrijf Koembe.

30. Koembe-M a ro coast

30.1. J. J. REYNDERS and J. P. ANDRIESSE (1957) : Een bodemkaartering van het kustgebied tussen de Marau en de Koembe.

30.2. H. SCHROO (1957) : Bodemvruchtbaarheidsrapport met analytische gegevens betreffende de gronden van het kustgebied tussen de Marau en de Koembe rivier.

30.3. H. SCHROO and W. L. P. J. MOUTHAAN (1958/59): Verslag der potproeven nr. 4, 5, 6, 7 en 8 met rijst, betreffende boven- en ondergronden van proefvelden in het rijstproefbedrijf "Koembe-Merauke".

30.4. K. A. HOMANS (1960) : Verslag over twee veldproeven met rijst op het Paal Poetih terrein bij Merauke.

30.5. B. SCHLETTE (1958) : Bodemdieptekaart van de grasvlakte bij Paal Poetih.

30.6. H. SCHROO (1959) : Een laboratoriumonderzoek van 33 paren boven- en ondergrondmonsters uit de onvergraven vlakte bij Paal Poetih.

30.7. H. SCHROO (1959) : Overzicht van bodemkundige onderzoekingen verricht in de jaren 1954 t/m 1959 t.b.v. het rijstproefbedrijf "Koembe" door het Bodemkundig Bureau te Hollandia.

30.8. K. A. HOMANS and H. SCHROO (1961): Verslag van een onderzoek naar de verzouting van het rivierwater bij Daroewan gelegen aan de Koembe rivier.

31. Coast south of Merauke

31.1. F. A. WENTHOLT (1941): Verslag van een bodemkundige verkenning van het kustgebied van Merauke.

31.2. J. H. DRUIF (1941) : Voorlopige beoordeling van de bodemkundige kaartering van de kustvlakte van Merauke.

31.3. F. H. N. RAZOUX SCHULTZ (1952): Terreinverslag van een bodemkundige opname van een deel van het kustgebied van Merauke.

31.4. W. J. VAN SOELEN 1957): Verslag van een bodemkundige opname van een gebied nabij Mopa (Merauke).

31.5. H. SCHROO (1960): Een vergelijkend onderzoek tussen het grondtype te Paal Poetih en dat te Mopa in het kustgebied van Merauke.

31.6. J. SCHWAN (1962): Een samenvattende bodemkundige verkenning van het Merauke kustgebied. 